\title{
PENGARUH KOMUNIKASI ORGANISASI DAN EFEKTIVITAS KEPEMIMPINAN TERHADAP KINERJA AGEN DI AJB BUMI PUTERA 1912 DIVISI SYARIAH CABANG SIDOARJO
}

Uswatun Hasanah

\author{
Universitas Islam Negeri Sunan Ampel Surabaya
}

hasanah@gmail.com

\section{Article Info}

\section{Article history:}

Received 16 August 2018

Accepted 15 September 2018

Published 10 Oktober 2018

Keyword:

Komunikasi organisasi, kepemimpian dan kinerja
Abstract

Penelitian membahas tentang Pengaruh Komunikasi Organisasi dan Efektivitas Kepemimpinan Terhadap Kinerja Agen di AJB Bumiputera 1912 Divisi Syariah Cabang Sidoarjo". Penelitian ini merupakan penelitian kuantitatif dengan analisis regresi linier berganda sebagai alat analisisnya. Untuk membuktikan hipotesis tersebut maka digunakan analisis linierberganda dengan uji signifikan $t$ dan F.

Hasil penelitian ini menunjukkan bahwa secara parsial variabel komunikasi organisasi memperoleh thitung $>$ ttabel $(2,293>2,0395)$ dan nilai signifikansi 0,029<0,05 dan untuk variabel efektivitas kepemimpinan memperoleh thitung $>$ ttabel $(3,349>2,0395)$ dan nilai signifikansi $0,002<0,05$. Sedangkan secara simultan kedua variabel mempunyai Fhitung $>$ Ftabel $(16,417>3,29)$ dan nilai signifikansi $0,000<0,05$. Sehingga dapat disimpulkan bahwa komunikasi organisasi dan efektivitas kepemimpinan berpengaruh signifikan terhadap kinerja agen baik secara parsial maupun simultan.

Berdasarakan hasil penelitian tersebut, diharapkan AJB Bumiputera 1912 Divisi Syariah Cabang Sidoarjo lebih meningkatkan komunikasi organisasi supaya hubungan antara pemimpin dengan agen selalu terjaga sehingga informasi-informasi penting lebih mudah dan cepat diperoleh baik untuk pemimpin maupun untuk agen sendiri, selain komunikasi organisasi, AJB Bumiputer 1912 Divisi Syariah Cabang Sidoarjo juga membutuhkan efektivitas kepemimpinan. 


\section{Pendahuluan}

Di Indonesia telah banyak bermunculan lembaga keuangan yang menggunakan prinsip syariah. Lembaga keuangan syariah adalah badan usaha yang melakukan kegiatan utamanya di bidang keuangan, dalam bentuk penghimpunan dan penyaluran dana, portofolio saham maupun obligasi serta bentuk lainnya sesuai prinsip-prinsip syariah. ${ }^{11}$ Lembaga keuangan syariah dibagi menjadi dua yaitu lembaga keuangan bank dan lembaga keuangan bukan bank. Salah satu lembaga keuangan bukan bank yang menggunakan prinsip syariah adalah asuransi. Asuransi merupakan salah satu cara yang dapat digunakan untuk membantu masyarakat dalam penyedia jaminan finansial.

Di Indonesia sendiri perusahaan asuransi syariah sekarang sudah mulai berkembang, Pada tahun 2015 sampai tahun 2016 jumlah perusahaan asuransi syariah dan unit asuransi syariah mengalami kenaikan, meskipun kenaikan ini tidak begitu banyak, dengan begitu, ini sudah menunjukkan bahwa usaha asuransi syariah di Indonesia telah berkembang. Dengan berkembangnya asuransi syariah di Indonesia, maka kompetisi usaha di bidang asuransi syariah akan semakin ketat. Untuk dapat bersaing, maka

\footnotetext{
${ }^{1}$ Nur Laila, et al., Lembaga Keuangan Islam Non Bank, (Surabaya: IAIN Sunan Ampel, 2013), 6-7

2 Sudarmanto, Kinerja dan Pengembangan Kompetensi SDM, (Yogyakarta: Pustaka Pelajar, 2009), 1

${ }^{3}$ Asosiasi Asuransi Syariah Indonesia, "Data Bisnis Asuransi dan Reasuransi Syariah Q1 2016", dalam http://www.aasi.or.id/page/data-bisnis-2016, di akses pada 19 April 2017

${ }^{4}$ Rangga Mahardhik et al, "Pengaruh Motivasi Terhadap Kinerja Karyawan (Jurnal—Universitas Brawijaya, Malang), 1.
}

perusahaan harus mempunyai strategi untuk dapat berkompetisi. Strategi untuk selalu dapat berkompetisi adalah dengan cara memperkuat kapasitas organisasi dan sumber daya manusia yang dimiliki. ${ }^{2}$

Sumber daya manusia merupakan faktor penentu atas keberhasilan suatu orgainisasi atau perusahaan dalam menjalankan visi, misi dan tujuanya. Sumber daya manusia memiliki tugas pokok yang sangat penting bagi kemajuan perusahaan. $^{3}$ Tenaga kerja memiliki potensi yang besar untuk menjalakan aktivitas perusahaan. Potensi setiap sumber daya manusia yang ada dalam perusahaan harus dapat dimanfaatkan sebaik-baiknya, sehingga mampu memberikan hasil yang maksimal. ${ }^{4}$ Apabila sumber daya manusia diperhatikan pada gilirannya akan memberikan kontribusi lebih tinggi bagi organisasi. $^{5}$ Sumber daya manusia merupakan roda penggerak yang sangat penting untuk memperoleh kinerja yang baik di dalam perusahaan. ${ }^{6}$

Kinerja adalah hasil kerja baik secara kualitas maupun kuantitas yang dicapai oleh seseorang dalam melaksanakan tugas sesuai tanggung jawab yang diberikan. ${ }^{7}$ Kinerja karyawan meliputi kualitas dan kuantitas output serta keandalan dalam bekerja. Karyawan dapat bekerja dengan

\footnotetext{
${ }^{5}$ Wibowo, Perilaku Dalam Organisasi, (Depok: PT RajaGrafindo Persada, 2016), 3

6 Adrew C. Johannes, et al., "Pengaruh Gaya Kepemimpinan, Kompensasi, Dan Lingkungan Kerja Terhadap Kinerja Agen Pada AJB Bumiputera 1912 Cabang Tikala", Jurnal Berkala Ilmiah Efisiensi No. 1, Vol. 16 (2016), 54

7 Anwar Prabu Mangkunegara, Managemen Sumber Daya Manusia, (Bandung: Remaja Rosdakarya, 2002), 22
} 
baik bila memiliki kinerja yang tinggi sehingga dapat menghasilkan kerja yang baik pula. Dengan adanya kinerja yang tinggi yang dimiliki karyawan, diharapkan tujuan organisasi dapat tercapai. Sebaliknya, tujuan organisasi susah atau bahkan tidak dapat tercapai bila karyawannya bekerja tidak memiliki kinerja yang baik sehingga tidak dapat menghasilkan kerja yang baik pula.

Menurut A. Dale Timle dalam Anwar Prabu, faktor-faktor kinerja terdiri dari faktor internal dan faktor eksternal. Faktor internal yaitu faktor yang dihubungkan dengan sifat-sifat seseorang. Sedangkat faktor eksternal yaitu faktorfaktor yang kinerja seseorang yang berasal dari lingkungan. Seperti perilaku, sikap, dan tindakan-tindakan rekan kerja, bawahan atau pimpinan, fasilitas kerja, iklim organisasi. ${ }^{8}$

Kinerja merupakan tolak ukur bagi perusahaan atau organisasi dari berhasil atau tidaknya tujuan yang telah ditetapkan tersebut, sehingga penting bagi perusahaan untuk mengetahui kinerja para karyawan, karena kinerja karyawan akan mempengaruhi kinerja perusahaan. Penilaian kinerja karyawan adalah suatu proses penilaian kinerja karyawan yang dilakukan oleh pimpinan organisasi secara sistematis berdasarkan pekerjaan yang ditugaskan kepadanya. Oleh karena itu, diperlukan pemimpin untuk dapat mengetahui bagaimana kinerja para karyawan perusahaan, ketika kinerja

\footnotetext{
${ }^{8}$ Anwar Prabu Mangkunegara, Evaluasi Kinerja SDM, (Bandung: PT Refika Aditama, 2012), 15

${ }^{9}$ Adrew C. Johannes, et al., 54

10 Edi Sutrisno, Budaya Organisasi, (Jakarta: Kencana, 2011), 175.
}

karyawan mulai merosot pemimpin akan dapat memilih tindakan yang tepat untuk memperbaiki kinerja tersebut, karena sesungguhnya seorang pemimpin dapat mempengaruhi kepuasan kerja, rasa aman, kualitas hidup karyawan dan tentunya prestasi dari perusahaan. ${ }^{9}$

Kepemimpinan merupakan faktor yang sangat penting dan bagaimana caranya seseorang memimpin hingga dapat membawa kelompok kerja ke arah keberhasilan yang maksimal. Untuk menciptakan kinerja organisasi bukan suatu hal yang mudah. Ini dikarenakan sikap dan perilaku manusia dalam organisasi sangat berbeda, sehingga berbeda pula dalam kemampuannya, kemauan, disiplin kejujuran dan motivasi. ${ }^{10}$ Oleh karena itu, dibutuhkan pemimpin yang memahami bagaimana keadaan dan apa yang dibutuhkan oleh setiap karyawan untuk memperoleh kinerja karyawan yang baik.

Menurut Contingency Theory Leadership menyatakan bahwa ada kaitan antara gaya kepemimpinan dengan situasi tertentu yang dipersyaratkan. Menurut teori ini seorang pemimpin akan efektif jika gaya kepemimpinannya sesuai dengan situasi yang terjadi. ${ }^{11}$

Teori ini mengemukakan bagaimana tindakan seorang manajer dalam situasi tertentu perilaku kepemimpinannya yang efektif. Artinya manajer dalam memperagakan kepemimpinannya tidak berpedoman pada salah satu pola perilaku

\footnotetext{
${ }^{11}$ Rivai dan Mulyadi, Kepemimpinan dan Perilaku organisasi, edisi ketiga, (Jakarta: PT Rajagrafindo Persada, 2010), 44
} 
dari waktu ke waktu melainkan didasarkan pada analisis manajer setelah ia mempelajari situasi tertentu, lalu melakukan pendekatan yang tepat. Apabila kemampuan motif serta kebutuhan bawahan sangat bervariasi, seorang pemimpin harus mempunyai kepekaan dan kemampuan mendiagnosa agar mampu membaca dan menerima perbedaanperbedaan.

Kepemimpinan merupakan kemampuan untuk mempengaruhi pihak lain. Keberhasilan seorang pemimpin tergantung kepada kemampuannya untuk mempengaruhi itu. Dengan kata lain kepemimpinan dapat diartikan sebagai kemampuan seseorang untuk mempengaruhi orang lain, melalui komunikasi baik langsung maupun tidak langsung dengan maksud untuk menggerakkan orang-orang tersebut agar dengan penuh pengertian, kesadaran dan senang hati bersedia mengikuti kehendak pemimpin. Seorang pemimpin yang efektif adalah seorang yang memiliki kemampuan tersebut. $^{12}$

Oleh karena itu, di dalam sebuah organisasi maupun perusahaan dibutuhkan komunikasi antara pemimpin dengan karyawan, Komunikasi adalah merupakan proses penyampain informasi dari satu pihak baik individu, kelompok maupun organisasi sebagai sender kepada pihak lain sebagai receiver untuk memahami dan terbuka peluang memberikan respon balik kepada sender. Pemimpin harus dapat berkomunikasi sebaik mungkin dengan para karyawan untuk menyampaikan

12 Pandji Anoraga, Psikologi Kepemimpinan, (Jakarta: Rineka Cipta, 2003), 2 maksud dan tujuan suatu organisasi agar mudah dipahami oleh karyawan. Kemampuan berkomunikasi dengan baik, baik secara lisan maupun tertulis, adalah keterampilan manajerial yang sangat penting dan landasan kepemimpinan yang efektif. Oleh karena itu, komunikasi memegang peranan yang sangat penting dalam interaksi sosial, sehingga berpengaruh dalam dunia kerja. Tempat kerja merupakan suatu komunitas sosial yang memfokuskan pada peran dari komunikasi, sehingga aktivitas kerja dapat dioptimalkan. Penggunaan komunikasi baik secara verbal maupun secara non verbal berpengaruh cukup besar pada lingkungan kerja yang diwujudkan dalam visi serta misi dari suatu perusahaan. Secara tidak langsung dibutuhkan komunikasi yang efektif dalam menggerakkan jalannya perusahaan, semakin efektif komunukasi yang dibina dalm tiap-tiap departemen, maka semakin produktif perilaku karyawan dalam menjalankan pekerjaan. ${ }^{13}$

Asuransi Jiwa Bersama Bumiputera 1912 merupakan perusahaan asuransi jiwa nasional yang pertama dan tertua di Indonesia. AJB Bumiputera 1912 juga telah membentuk Divisi Asuransi Jiwa Syariah dan Cabang Asuransi Jiwa Syariah, hal itu dikarenakan semakin meningkatnya kesadaran umat untuk bermuamalah sesuai prinsip syariah dan juga tuntutan lembaga keuangan syariah yang mulai banyak diminati oleh masyarakat Indonesia. Salah satu kantor

\footnotetext{
${ }^{13}$ Edi Sutrisno, Budaya..., 41.
} 
cabang asuransi jiwa syariah yang di miliki

AJB Bumiputera 1912 berada di Sidoarjo.

AJB Bumiputera 1912 Divisi Syariah

Cabang Sidoarjo berdiri pada tahun 2007.

Di AJB Bumiputera 1912 Divisi Syariah

Cabang Sidoarjo dalam penjualan premi mengalami fluktuasi, hal ini di tunjukkan pada tabel 1.2. Pada bulan Oktober, November dan Desember 2015 jumlah premi mengalami penurunan, sedangkan pada bulan Januari, Februari, dan Maret 2016 jumlah premi mengalami peningkatan, namun pada bulan April dan Mei 2016 jumlah premi mengalami penurunan lagi. Selain itu, setiap kantor cabang mempunyai target penjualan premi yang harus dicapai setiap bulannya, target penjual premi AJB Bumiputera 1912 Divisi Syariah Cabang Sidarjo dalam satu bulan adalah Rp 790.934.666,67 dan jika target penjualan premi tersebut dibandingkan dengan hasil penjulan premi. maka hasil penjualan premi sangat jauh dengan target penjualan premi yang harus dicapai. Hal ini menunjukkan bahwa kurang maksimalnya kinerja agen di AJB Bumiputera 1912 Divisi Syariah Cabang Sidoarjo dalam penjulan premi.

\section{Berdasarkan}

pengamatan

sebelumnya, diketahui bahwa pekerjaan para agen di AJB Bumiputera 1912 Divisi Syariah Cabang Sidoarjo banyak dilakukan dilapangan dikarenakan tugas para agen adalah memasarkan produk, hal ini menjadikan intensitas pertemuan pemimpin dengan para agen jarang terjadi dan pertemuan dilakukan sebatas pada halhal yang bersifat formal yaitu pada rapat rutin yang membahas masalah pekerjaan. Hal ini membuat kedekatan antara pemimpin dengan para agen berkurang, padahal salah satu syarat untuk membuat terjalinnya hubungan yang akrab dan harmonis antara pemimipin dengan bawahan adalah intensitas pertemuan yang rutin.

Oleh karena itu, kepala cabang harus selalu memperhatikan situasi yang ada dalam perusahaan, sehingga dibutuhkan kepemimpinan yang efektif agar dapat memilih tindakan yang tepat untuk para agen ketika penjualan produk menurun, karena agen adalah penentu atas keerhasilan perusahaan dalam pemasaran produk. Selain kepemimpinan yang efektif juga dibutuhkan komunikasi organisasi agar dapat terjalin hubungan yang akrab dan harmonis antara kepala cabang dengan para agen, sehingga memudahkan kepala cabang untuk memberi informasi penting mengenai pekerjaan yang harus dilakukan, dan juga untuk menggali informasi dari para agen tentang bagaimana dengan pekerjaan yang telah dilakukan, selain itu juga memudahkan kepala cabang untuk mengontrol kinerja agen.

\section{Kajian Pustaka}

\section{Konsep Komunikasi organisasi}

Komunikasi adalah pengiriman dan penerimaan pesan atau berita antara dua orang atau lebih sehingga pesan dimaksud dapat dipahami. Komunikasi juga sebagai proses pemidahan pengertian dalam bentuk gagasan atau informasi dari seseorang kepada orang lain. Selain itu komunkasi diartikan sebagai proses penyampaian informasi atau pengiriman dari seseorang kapada orang lain. ${ }^{1}$ Sedangkan organisasi adalah suatu koordinasi rasional kegiatan 
sejumlah orang untuk mencapai hierarki otoritas dan tanggung jawab. ${ }^{14}$

Komunikasi organisasi dapat didefinisikan sebagai pertunjukan dan penafsiran pesan di antara unit-unit komunikasi yang merupakan bagian dari suatu organisasi tertentu. Suatu organisasi terdiri dari unit-unit komunikasi dalam hubungan-hubungan hierarkis antara yang satu dengan lainnya dan berfungsi dalam suatu lingkungan. ${ }^{15}$

Sedangkan Wiryanto dalam dalam

Yulius Eka menyatakan, komunikasi organisasi adalah pengiriman dan penerimaan berbagai pesan organisasi di dalam kelompok formal maupun informal dari suatu organisasi. ${ }^{16}$

Komunikasi mempunyai empat fungsi utama dalam sebuah kelompok atau organisasi, yaitu: fungsi kendali, motivasi, pengungkapan emosi dan informasi. Komunikasi berfungsi untuk mengendalikan perilaku anggotanya dalam beberapa cara. Organisasi mempunyai otoritas hierarkis dan pedoman resmi di mana angota-anggotanya diwajibkan untuk mematuhinya. Sebagai contoh, para karyawan wajib untuk mengkomunikasikan keluhan yang berhubungan dengan pekerjaan kepada atasan langsungnya, untuk mengetahui rincian kerja mereka, atau untuk memaksa mereka tunduk pada peraturan perusahaan,

14 Arni Muhammad, Komunikasi Organisasi, (Jakarta: PT Bumi Askara, 2005), 23

${ }^{15}$ R. Wayne Pace dan Don F Faules, Komunikasi Organisasi Strategi Meningkatkan Kinerja Perusahaan, (Bandung: PT Remaja Rosdakarya, 1998), 31

16 Stephen P.Robbins, Perilaku Organisasi, Edisi kelima, (Jakarta: Erlangga, 2002), 146. komunikasi ini melaksanakan fungsi kendali. ${ }^{17}$

Komunikasi memperkuat motivasi dengan klarifikasi pada pekerja apa yang harus mereka kerjakan, seberapa baik mereka melakukan, dan bagaimana memperbaiki apabila dibawah standar. Pembentukan tujuan spesifik, umpan balik progress terhadap tujuan dan reward atas perilaku yang diharapkan, semua menstimulasi motivasi dan memerlukan komunikasi. $^{18}$

\section{Proses Komunikasi}

Proses komunikasi adalah langkahlangkah antara satu sumber dan penerima yang menghasilkan pentrasferan dan pemahaman makna. Proses ini dimulai dari Komunikator menyampaikan pesan, melalui media tertentu, disampaikan kepada komunikan, kemudian menimbulkan efek dan umpan balik. ${ }^{19}$

Sedangkan dalam proses komunikasi organisasi kita berbicara tentang informasi yang berpindah secara formal dari seseorang yang otoritasnya lebih tinggi kepada orang yang otoritasnya lebih rendah - komunikasi ke bawah; informasi yang bergerak dari suatu jabatan yang otoritasnya lebih tinggi - komunikasi ke atas; informasi yang bergerak diantara orang-orang dan jabatan-jabaqtan yang sama tingkat tingkat otoritasnya komunikasi horisontal; atau informasi

17 Stephen P.Robbins, Perilaku Organisasi, Edisi kelima, (Jakarta: Erlangga, 2002), 146.

18 Wibowo, Perilaku Dalam Organisasi, (Depok: PT RajaGrafindo Persada, 2016), 166

${ }^{19}$ Suwarto, Perilaku Keorganisasian, Edisi Revisi, (Yogyakarta: Universitas Atma Jaya Yogyakarta, 2010), 191 
yang bergerak diantara orang-orang dan jabatan-jabatan yang tidak menjadi atasan ataupun bawahan satu dengan yang lainnya dan mereka menempati bagian fungsional yang berbeda - komunikasi lintas-saluran. Kita juga menyinggung informasi yang mengalir secara informal bersama-sama "selentingan'. ${ }^{20}$ Lebih jelasnya sebagaimana dibawah ini.

Pertama, komunikasi ke bawah dalam sebuah organisasi berarti bahwa informasi mengalir dari jabatan berotoritas lebih tinggi kepada mereka yang berotoritas lebih rendah. Komunikasi ke bawah biasanya diberikan oleh pemimpin kepada bawahan atau kepada para anggota organiasi dengan tujuan untuk memberikan pengertian mengenai apa yang harus dikerjakan oleh para anggota sesuai dengan kedudukannya. Pesan-pesan tersebut dapat dijalankan melalui kegiatan: pengarahan, petunjuk, perintah, teguran, penghargaan, dan keterangan umum. Komunikasi ke bawah juga dimaksudkan untuk merubah sikap, membentuk pendapat, mengurangi kekuatan, dan kecurigaan yang timbul karena kesalahan informasi, dan mempersiapkan anggota organiasi untuk menyesuaikan diri dengan perubahanperubahan. Komunikasi ke bawah ini dapat diberikan secara lisan, tertulis, dengan gambar atau simbol-simbol, dalam bentuk surat edaran, pengumuman atau buku-buku pedoman karyawan atau anggota. ${ }^{21}$

Kedua, Komunikasi ke atas dalam sebuah organisasi berarti bahwa informasi mengalir dari tingkat yang lebih rendah

${ }^{20}$ R. Wayne Pace dan Don F Faules, Komunikasi Organisasi..., 170

${ }^{21}$ Yulius Eka Agung Seputra, Manajemen dan..., $156-157$ (bawahan) ke tingkat yang lebih tinggi (penyelia). Komunikasi ke atas adalah pesan yang mengalir dari bawah ke atas, yakni pesan yang disampaikan oleh para anggota atau bawahan kepada pimpinan Komunikasi ini dimaksudkan untuk memberikan masukan, saran bahan-bahan yang diperlukan oleh pimpinan dapat melaksanakan fungsi sebaik-baiknya. Selain itu komunikasi ke atas ini juga menjadi saluran bagi para anggota atau karyawan untuk menyampaikan pikiran, perasaan berkaitan dengan tugas-tugasnya. Hal ini dapat dilakukan melalui kegiatan: pemberian laporan, pemberian saran atau pendapat, baik secara lisan tertulis atau dengan menggunakan simbol dan gambar. $^{22}$

Ketiga, Komunikasi horisontal terdiri dari penyampaian informasi di antara rekan-rekan sejawat dalam unit kerja yang sama. Unit kerja meliputi individu-individu yang ditempatkan pada tingkat otoritas yang sama dalam organisasi dan mempunyai atasan yang sama. Pesan yang disampaikan biasanya berhubungan degan tugas-tugas, tujuan kemanusiaan, saling memberi informasi, penyelesaian konfilk dengan koordinasi. Koordinasi diperlukan untuk mencegah tendensi-tendensi, selain itu juga dimaksudkan untuk memelihara keharmonisan dalam organisasi. Kegiatan ini dapat dilakukan dengan cara: rapatrapat komite, interaksi informal, memo dan nota, dan lain-lain. ${ }^{23}$

22 Yulius Eka Agung Seputra, Manajemen dan..., 157-158

23 Yulius Eka Agung Seputra, Manajemen dan..., 157. 
Keempat, Komunikasi LintasSaluran, Informasi yang bergerak diantara orang-orang dan jabatan-jabatan yang tiedak menjadi atasan ataupun bawahan satu dengan yang lainnya dan mereka menempati bagian fungsional yang berbeda. Komunikasi lintas-saluran, yaitu informasi diberikan melewati batas-batas fungsional atau batas-batas unit kerja, dan di antara orang-orang yang satu sama lainnya tidak saling menjadi bawahan atau atasan. $^{24}$

Kelima, Komunikasi Informal, Adalah komunikasi yang terjadi di antara para anggota organisasi atas dasar kehendak pribadi, tanpa memperhatikan posisi atau kedudukan mereka dalam organisasi. Informasi dalam komunikasi informal ini mengalir ke atas, ke bawah, atau secara horisontal, dan ini terjadi ketika komunikasi formal kurang memuaskan anggota akan informasi yang diperlukan. Komunikasi informal disebut juga dengan dengan grapevine (desas desus) cenderung berisi laporan rahasia mengenai orang, atau kejadian-kejadian diluar arus dari arus informasi yang mengalir secara resmi. Namun walaupun informasinya bersifat informal, grapevine ini bermanfaat bagi organisasi. $^{25}$

\section{Metode Penelitian}

Penelitian ini membahas mengenai Pengaruh Komunikasi Organisasi dan Efektivitas Kepemimpinan terhadap

\footnotetext{
${ }^{24}$ R. . Wayne Pace dan Don F Faules, Komunikasi Organisasi..., 184

${ }^{25}$ Yulius Eka Agung Seputra, Manajemen dan..., 158
}

Kinerja Agen di AJB Bumiputera 1912 Divisi Syariah Cabang Sidoarjo. Penelitian ini menggunakan penelitian kuantitatif yang bertujuan untuk menggambarkan, meringkas berbagai kondisi, berbagai situasi atau berbagai variabel yang timbul di masyarakat yang menjadi objek penelitian. Metode yang digunakan di dalam penelitian ini adalah metode survey, yaitu metode pengumpulan data dengan mengambil sampel dan populasi dan menggunakan kuesioner sebagai instrumen pengumpulan data utama yang disebarkan peneliti. ${ }^{26}$

Populasi adalah wilayah generalisasi yang terdiri atas: obyek/subyek mempunyai kualitas dan karakteristik tertentu yang ditetapkan oleh peneliti untuk dipelajari dan kemudian ditarik kesimpulannya. Populasi yang akan dianalisis dalam penelitian ini adalah seluruh agen di AJB Bumiputera 1912 Divisi Syariah Cabang Sidoarjo yang berjumlah 34 orang.

Sampel adalah bagian dari jumlah dan karakteristik yang dimiliki oleh populasi tersebut. Menurut Suharsimi Arikunto, Pengambilan sampel terhadap subyek penelitian yang kurang dari 100 orang lebih baik diambil semua, sehingga penelitiannya merupakan penelitian populasi. ${ }^{27}$ Dalam penelitian ini, jumlah populasi kurang dari 100, maka semua populasi dijadikan sampel penelitian. Oleh karena itu, sampel yang diambil untuk

\footnotetext{
26 Burhan Bungin, Metodologi Penelitian Sosial (Format-Format Kuantitatif dan Kualitatif), (Surabaya: Airlangga University Perss, 2001), 48

${ }^{27}$ Suharsimi Arikunto, Prosedur Penelitian Suatu Pendekatan Praktik, (Jakarta: Rineka Cipta, 2006), 134
} 
penelitian ini sebanyak 34 orang agen di AJB Bumiputera 1912 Divisi Syariah Cabang Sidoarjo.

\section{Hasil dan Pembahasan}

\section{Profil Asuransi Jiwa Bersama Bumiputera 1912 Syariah}

Asuransi Jiwa Bersama Bumiputera 1912 atau lebih dikenal sebagai AJB Bumiputera 1912 adalah perusahaan asuransi jiwa nasional milik bangsa Indonesia yang pertama dan tertua. Didirikan pada tanggal 12 Februari 1912 di Magelang Jawa Tengah atas prakarsa seorang guru sederhana bernama M. Ng. Dwidjosewojo Sekretaris Persatuan Guru Hindia Belanda (PGHB) sekaligus Sekretaris pengurus besar Budi Utomo.

Gagasan pendirian perusahaan asuransi jiwa ini, terdorong oleh keprihatinan mendalam terhadap nasib para guru bumiputera (pribumi). Dalam pendirian tersebut M. Ng. Dwidjosewojo dibantu oleh dua orang guru lainnya yaitu MKH. Soebroto dan M. Adimodjojo.

Tidak seperti perusahaan berbentuk perseroan terbatas (PT) yang kepemilikannya hanya oleh pemodal tertentu, sejak awal pendiriannya Bumiputera sudah menganut sistem kepemilikan dan kepengurusan yang unik, yakni bentuk badan usaha "mutual" atau "usaha bersama"

Semua pemegang polis adalah pemilik perusahaan yang mempercayakan wakil-wakil mereka di Badan Perwakilan Anggota (BPA) untuk mengawasi jalannya perusahaan. Perjalanan Bumiputera kini mencapai seabad lebih. Perjalanan panjang itu tentu saja tidak lepas dari pasang surut.
Memasuki millennium ketiga, Bumiputera mempunyai jaringan lebih dari 600 kantor yang tersebar di seluruh pelosok Indonesia.

Unit syariah AJB Bumiputera 1912 secara resmi terbentuk sejak dikeluarkan surat Keputusan Menteri Keuangan No. Kep. 286/KMK.6/2002 tanggal 7 November 2002 dalam bentuk cabang usaha Asuransi Jiwa Syariah dan Fatwa Dewan Syariah Nasional No. 21/DSNMUI/X/2001, 17 oktober 2001. Dalam rangka menjaga kemurnian pelaksanaan prinsip-prinsip syariah, maka berdasarkan keputusan Direksi No. SK. 14/DIR/2002, tanggal 11 November 2002 dibentuk Divisi Asuransi Syariah dan kantor Cabang Asuransi Syariah Jakarta.

Pengaruh Komunikasi Organisasi dan Efektivittas Kepemimpinan secara Parsial Terhadap Kinerja Agen di AJB Bumiputera 1912 Divisi Syariah Cabang Sidoarjo

Berdasarkan hasil analisis uji $\mathrm{t}$ (parsial) yang telah di uraikan dalam bab empat, maka dalam bab lima akan dibahas lebih lanjut hasil perhitungan yang telah didapatkan untuk mendapatkan gambaran hasil penelitian yang jelas. Secara parsial variabel independen komunikasi organisasi berpengaruh secara signifikan terhadap variabel dependen kinerja agen di AJB Bumiputera 1912 Divisi Syariah Cabang Sidoarjo, begitu juga variabel independen efektivitas kepemimpinan juga berpengaruh secara signifikan terhadap variabel dependen kinerja agen di AJB Bumiputera 1912 Divisi Syariah Cabang Sidoarjo. 
1. Variabel Komunikasi Organisasi (X1)

Berdasarkan uji t (Parsial) maka diperoleh nilai thitung sebesar 2,293 yang lebih besar dari ttabel yaitu 2,0395, sedangkan nilai signifikansi yang diperoleh adalah 0,029 yang lebih kecil dari 0,05 sehingga dapat disimpulkan bahwa variabel komunikasi organisasi secara parsial berpengaruh signifikan terhadap variabel kinerja agen di AJB Bumiputera 1912 Divisi Syariah Cabang Sidoarjo. Dengan demikian hipotesis yang berbunyi "Komunikasi organisasi (X1) secara parsial terdapat pengaruh terhadap kinerja agen di AJB Bumiputera 1912 Divisi Syariah Cabang Sidoarjo" diterima.

Hasil penelitian ini didukung oleh penelitian sebelumnya yang dilakukan oleh Desy Ernika (2016) dengan judul "Pengaruh Komunikasi Organisasi dan Motivasi terhadap Kinerja Karyawan pada PT. Inti Tractors Samarinda". Hasil penelitian Desy Ernika tersebut menunjukkan bahwa terdapat pengaruh antara komunikasi organisasi dengan kinerja karyawan.

Setiap komunikasi organisasi yang dilakukan merupakan faktor yang penting untuk meningkatkan kinerja agen. Maka kontribusi setiap variabel komunikasi organisasi akan mempengaruhi kinerja agen di AJB Bumiputera 1912 Divisi Syariah Cabang Sidoarjo.

Komunikasi memegang peranan yang sangat penting dalam interaksi sosial, sehingga berpengaruh dalam dunia kerja. Tempat kerja merupakan suatu komunitas sosial yang memfokuskan pada peran dari komunikasi, sehingga aktivitas kerja dapat dioptimalkan. Penggunaan komunikasi baik secara verbal maupun secara non verbal berpengaruh cukup besar pada lingkungan kerja yang diwujudkan dalam visi serta misi dari suatu perusahaan.

Di AJB Bumiputera 1912 Divisi Syariah Cabang Sidoarjo untuk menjaga komunikasi organisasi, pemimpin mengadakan rapat rutin untuk seluruh agen, rapat rutin tersebut dilakukan setiap satu bulan sekali dan dilakukan satu minggu sekali. Rapat rutin yang diadakan satu bulan sekali akan membahas mengenai evaluasi untuk bulan sebelumnya serta estimasi penjulan yang harus di capai pada bulan yang berjalan, sedangkan rapat rutin yang diadakan setiap satu minggu sekali yaitu pada hari Rabu akan membahas mengenai pemasukan yang sudah diperoleh agen dan membahas penagihan yang sudah dilakukan agen. Selain rapat rutin, untuk lebih menjaga komunikasi organisasi setiap harinya, AJB Bumiputera 1912 Divisi Syariah Cabang Sidoarjo melakukan komunikasi melalui sosial media yaitu grup WhatsApp. Ini akan lebih memudahkan kepala cabang sebagai pemimpin memantau pekerjaan para agen di lapangan setiap harinya serta dapat langsung memberikan informasiinformasi penting. Selain itu ketika terjadi masalah di lapangan, agen dapat langsung mengkomunikasikan dengan 
kepala cabang supaya langsung mendapatkan solusi untuk mengatasi masalah tersebut.

\section{Variabel Efektivitas Kepemimpinan} (X2)

Berdasarkan uji t (Parsial) maka diperoleh nilai thitung sebesar 3,349 yang lebih besar dari ttabel yaitu 2,0395, sedangkan nilai sinifikansi yang diperoleh adalah 0,002 yang lebih kecil dari 0,05 sehingga dapat disimpulkan bahwa variabel efektivitas kepemimpinan secara parsial berpengaruh signifikan terhadap variabel kinerja agen di AJB Bumiputera 1912 Divisi Syariah Cabang Sidoarjo. Dengan demikian hipotesis yang berbunyi "Efektivitas kepemimpinan (X2) secara parsial terdapat pengaruh terhadap kinerja agen di AJB Bumiputera 1912 Divisi Syariah Cabang Sidoarjo" diterima.

Hasil penelitian ini didukung oleh penelitian sebelumnya yang dilakukan oleh Adi Robith Setiana dengan judul "Pengaruh Efektivitas Kepemimpinan Kepala Sekolah dan Motivasi Kerja terhadap Kinerja Guru (Studi Kasus pada MTs Serba Bakti Pondok Pesantren Suryalaya Kab. Tasikmalaya". ${ }^{5}$ Hasil penelitian tersebut menunjukkan bahwa terdapat pengaruh yang signifikan efektivitas kepemimpinan terhadap kinerja guru. Selain itu, penelitian ini juga didukung oleh Rasmuji dan Ratnawati Dwi Putranti dengan judul "Pengaruh Efektivitas Kepemimpinan dan Lingkungan Kerja terhadap Kinerja
Karyawan dengan Peran Mediasi Kepuasan Kerja (Studi pada PD. BPR BKK Batang)".

Setiap efektivitas kepemimpinan yang dilakukan merupakan faktor yang penting untuk meningkatkan kinerja agen. Maka kontribusi setiap variabel efektivitas kepemimpinan akan mempengaruhi kinerja agen AJB Bumiputera 1912 Divisi Syariah Cabang Sidoarjo.

Peran utama seorang pemimpin adalah mempengaruhi orang lain untuk secara sukarela mencapai sasaran yang ditetapkan. ${ }^{7}$ Keberhasilan organisasi sangat ditentukan oleh bagaimana kepemimpinan dalam organisasi itu dapat dijalankan secara efektif. Efektivitas kepemimpinan merupakan faktor yang sangat penting dalam penentuan keberhasilan organisasi dalam mewujudkan tujuannya.

Seorang pemimpin akan efektif jika gaya kepemimpinannya sesuai dengan situasi yang terjadi. Seorang pemimpin dalam memimpinan perusahaan atau organisasi tidak berpedoman pada salah satu pola perilaku dari waktu ke waktu, melainkan didasarkan pada analisis setelah ia mempelajari situasi yang ada, lalu melakukan pendekatan yang tepat yang nantinya akan meningkatkan kinerja.

Kepemimpin di AJB Bumiputera 1912 Divisi Syariah Cabang Sidoarjo dipegang oleh seorang kepala cabang. Maka kepala cabang harus selalu memperhatikan situasi yang terjadi didalam perusahaan. Selain itu, kepala 
cabang harus dapat memilih tindakantindakan yang tepat untuk mempengaruhi agen, sehingga agen dapat mencapai target penjualan premi yang telah ditentukan.

Kepala cabang dalam menjaga hubungan dengan agen adalah dengan selalu menjaga komunikasi dengan para agen. Ketika agen berada memberikan hasil penagihan preemi atau untuk urusan lain di kantor maka kepala cabang biasanya berkomunikasi dengan agen tersebut untuk membahas masalah pekerjaan yang telah dilakukan di lapangan. Selain itu, untuk menjaga hubungan dengan agen, kepala cabang juga memperhatikan penjualan setiap agen. Ketika salah satu agen mempunyai masalah dengan penjualan produknya, maka kepala cabang akan langsung dapat memberikan saran dalam menangani masalah tersebut serta memberikan dorongan semangat kepada agen agar lebih semangat dalam menjual produk.

Kepala cabang juga akan menentukan target penjulan premi kepada setiap agen berbeda-beda, sesuai dengan kemampuan dan pengalaman agen tersebut karena setiap agen mempunyai kualitas yang berbeda-beda. Untuk agen yang sudah lama, kepala cabang akan memberikan target penjualan yang lebih besar, sedangkan untuk agen yang baru maka kepala cabang memberikan target yang lebih sedikit. Selain itu, untuk para agen baru kepala cabang selalu memberikan cara-cara untuk menjual produk asuransi serta cara-cara untuk menghadapi nasabah dan cara berkomunikasi yang baik dengan nasabah.

Pengaruh Komunikasi Organisasi dan Efektivittas Kepemimpinan secara Simultan Terhadap Kinerja Agen di AJB Bumiputera 1912 Divisi Syariah Cabang Sidoarjo

Dalam pengaruh komunikasi organisasi dan efektivitas

kepemiminan terhadap kinerja agen di AJB Bumiputera 1912 Divisi Syariah Cabang Sidoarjo berdasarkan uji simultan (uji F ) yang dilakukan, dapat dilihat dari tabel ANOVA yang menunjukkan bahwa nilai Fhitung sebesar 16,417 yang lebih besar dari Fttabel yaitu 3,29 sedangkan nilai sinifikansi yang diperoleh adalah sebesar 0,000 yang lebih kecil dari 0,05. Maka komunikasi organisasi secara bersama-sama mempunyai pengaruh yang positif dan signifikan terhadap kinerja agen di AJB Bumiputera 1912 Divisi Syariah Cabang Sidoarjo.

Hasil penelitian ini menunjukkan bahwa berbagai variabel yang diikutsertakan dalam penelitian ini sebagai variabel independen apabila bersama-sama akan memiliki pengaruh yang pengaruh yang positif dan signifikan terhadap kinerja agen. Artinya semakin tinggi kegiatan komunikasi organisasi (X1) dan efektivitas kepemimpinan (X2), maka akan semakin tinggi pula kinerja agen di AJB Bumiputera 1912 Divisi Syariah Cabang Sidoarjo.

Kemudian jika dilihat dari koefisien determinasi menunjukkan bahwa kedua vaiabel independen yaitu X1 (komunikasi organisasi) dan X2 (efektivitas 
kepemimpinan) berpengaruh terhadap variabel dependen yaitu kinerja agen sebesar 0,514 atau $51,4 \%$, dimana angka tersebut adalah tinggi karena diatas $50 \%$ atau cenderung mendekati $100 \%$.

Hasil penelitian ini didukung oleh penelitian sebelumnya yang dilakukan oleh Budi Prijanto, Agustin Rusiana Sari, dan Fitriansyah Hambali dengan judul "Pengaruh Efektivitas Komunikasi dan Kepemimpinan terhadap Kinerja Organisasi (Studi Kasus : Badan Eksekutif Mahasiswa - Fakultas Ekonomi Universitas Gunadarma Periode 20102011)".9 Hasil penelitian tersebut menunjukkan bahwa secara simultan efektivitas komunikasi dan kepemimpinan berpengaruh terhadap kinerja organisasi.

Komunikasi organisasi merupakan suatu bagian yang sangat penting dalam suatu sistem pengendalian organisasi, yang pada hakekatnya adalah untuk mencapai suatu tujuan melalui kinerja. Begitu juga efektivitas kepemimpinan merupakan faktor yang sangat penting dalam penentuan keberhasilan organisasi dalam mewujudkan tujuan perusahaan. Oleh karena itu, komunikasi organisasi dan efektivitas kepemimpinan mempunyai pengaruh terhadap kinerja suatu perusahaan.

Dalam meningkatkan kinerja agennya, AJB Bumiputera 1912 Divisi Syariah Cabang Sidoarjo telah melakukan komunikasi organisasi dan efektivitas kepemimpinan dengan baik, hal ini dibuktikan dengan hasil penelitian yang menunjukkan bahwa nilai Fhitung lebih besar dari Fttabel. Dalam menjaga kmunikasi organisasi, AJB Bumiputera
1912 Divisi Syariah Cabang Sidoarjo mengadakan rapat rutin setiap satu bulan sekali dan setiap satu minggu sekali. Selain rapat, komunikasi organisasi dilakukan melalui sosial media dan juga ketika agen sedang berada di kantor.

Sedangkan untuk memperoleh efektivitas kepemimpinan, kepala cabang menjaga hubungan dengan agen dengan cara memperhatikan perkerjaan para agen dan menjaga komunikasi setiap harinya dengan menyapa para agen melalui grup social media. Selain itu, untuk struktur tugas pemimpin memberikan penjualan premi kepada setiap agen berbeda, sesuai dengan kemampuan pengalaman agen tersebut, hal ini dilakukan agar pekerjaan lebih efektif dan ketika penjualan premi meningkat kepala cabang akan mengadakan rapat di luar kota, hal ini dilakukan untuk memberi semangat dan motivasi kepada agen agar lebih bersemangat lagi dalam menjual premi. Dengan demikian, komunikasi organisasi dan efektivitas kepemimpinan yang dilakukan AJB Bumiputera 1912 Divisi Syariah Cabang Sidoarjo dapat meningkatkan kinerja agen.

\section{Kesimpulan}

Berdasarkan penelitian yang dilakukan, dapat disimpulkan sebagai berikut;

Dari hasil uji t parsial diketahui bahwa secara parsial variabel komunikasi organisasi berpengaruh signifikan terhadap kinerja agen di AJB Bumiputera 1912 Divisi Syariah Cabang Sidoarjo dengan nilai thitung lebih besar dari ttabel yaitu 2,293> 2,0395 nilai signifikansi yang 
diperoleh adalah 0,029 yang lebih kecil dari 0,05 . Sehingga hipotesis yang pertama yang menyatakan bahwa "Terdapat pengaruh yang signifikan antara komunikasi organisasi terhadap kinerja agen di AJB Bumiputera 1912 Divisi Syariah Cabang Sidoarjo" diterima.

Dari hasil uji t parsial diketahui bahwa secara parsial variabel efektivitas kepemimpinan berpengaruh signifikan terhadap kinerja agen di AJB Bumiputera 1912 Divisi Syariah Cabang Sidoarjo dengan nilai thitung lebih besar dari ttabel yaitu 3,349>2,0395 nilai signifikansi yang diperoleh adalah 0,002 yang lebih kecil dari 0,05 . Sehingga hipotesis yang kedua yang menyatakan bahwa "Terdapat pengaruh yang signifikan antara efektivitas kepemimpinan terhadap kinerja agen di AJB Bumiputera 1912 Divisi Syariah Cabang Sidoarjo" diterima.

Terdapat pengaruh yang signifikan secara simultan antara variabel komunikasi organisasi dan efektivitas kepemimpinan terhadap kinerja agen di AJB Bumiputera 1912 Divisi Syariah Cabang Sidoarjo, karena memiliki nilai Fhitung lebih besar dari Ftabel yaitu 16,417> 3,29 dan memiliki nilai signifikansi sebesar 0,000 yang lebih kecil dari 0,005.

Sehingga hipotesis yang ketiga yang menyatakan bahwa "Terdapat pengaruh yang signifikan antara komunikasi organisasi dan efektivitas kepemimpinan terhadap kinerja agen di AJB Bumiputera 1912 Divisi Syariah Cabang Sidoarjo" diterima.

\section{Daftar Pustaka}

Alhusin, Syahri. Aplikasi Statistik Praktis dengan SPSS.10 for Windows. Edisi

Kedua. Yogyakarta: Graha Ilmu, 2003.

Anoraga, Pandji. Psikologi Kepemimpinan. Jakarta: Rineka Cipta, 2003.

Arikunto, Suharsimi. Prosedur Penelitian Suatu Pendekatan Praktik. Jakarta: Rineka Cipta, 2006.

Asosiasi Asuransi Syariah Indonesia. "Data Bisnis Asuransi dan Reasuransi Syariah Q1 2016”, dalam http://www.aasi.or.id/page/databisnis-2016, di akses pada 19 April 2017.

As'ad, Moh. Psikologi Industri. Jakarta: PT Rineka Cipta, 1991.

Bungin, Burhan. Metode Penelitian Sosial \& Ekonomi Format-format Kuantitatif untuk Studi Sosial, Keijakan Publik, Komunikasi, Manajemen dan Pemasaran. Jakarta: Kencana, 2013.

Bungin, Burhan. Metodologi Penelitian Kuantitatif. Jakarta: Kencana, 2005.

Bungin, Burhan. Metodologi Penelitian Sosial (Format-Format Kuantitatif dan Kualitatif). Surabaya: Airlangga University Perss, 2001.

Daft, Richard L. Manajemen. Edisi Enam. Buku Dua. Jakarta: Salemba Empat, 2006.

Departemen Agama RI. Al-Qur'an Tafsir Per Katata Tajwid Kode Angka. Tangerang Selatan: P.T Kalim, 2010.

Ernika, Desy "Pengaruh Komunikasi Organisasi dan Motivasi terhadap Kinerja. 
Karyawan pada PT Inti Tractors Smarinda", eJournal Ilmu Komunikasi, 4 (2), 2016.

Ghozali, Imam. Ekonometrika: Teori, Konsep, dan Aplikasi dengan SPSS 17.

Semarang: Badan Penerbit Universitas Diponegoro, 2007.

Hasan, Iqbal. Analisis Data Penelitian dengan Statistik. Jakarta: PT. Bumi Aksara, 2006.

Hasmayati, Yanti. "Pengaruh Efektivitas Kepemimpinan Kepala Sekolah dan Motivasi Kerja Terhadap Kompetensi Guru (Studi pada Jurusan Bisnis dan Manajemen Sekolah Menengah Kejuruan Negeri dan Swasta di Kabupaten Sumedang)", Jurnal Manajerial, No. 18, Vol. 9, Januari, 2011.

Johannes, Adrew C., et al., "Pengaruh Gaya Kepemimpinan, Kompensasi, Dan Lingkungan Kerja Terhadap Kinerja Agen Pada AJB Bumiputera 1912

Cabang Tikala", Jurnal Berkala Ilmiah Efisiensi, No. 1, Vol.16, 2016.

Laila, Nur. et al., Lembaga Keuangan Islam Non Bank. Surabaya: IAIN Sunan Ampel, 2013.

Mahardhik, Rangga. et al., "Pengaruh Motivasi Terhadap Kinerja Karyawan".

Mangkunegara, Anwar Prabu, Evaluasi Kinerja SDM. Bandung: PT Refika Aditama, 2012.

Mangkunegara, Anwar P, Managemen Sumber Daya Manusia. (Bandung: Remaja Rosdakarya, 2002.

Mangkunegara, Anwar Prabu. Manajemen Sumber Daya Manusia Perusahaan. Bandung: PT Remaja Rosdakarya, 2000 .
Muhammad. Metodologi Penelitian Ekonomi Islam: pendekatan Kuantitatif. Jakarta: Rajawali Pers, 2008.

Muhid, Abdul. Analisis Statistik (5 langkah Praktis Analisis Statistik dengan

SPSS for Window). Surabaya: Lembaga Penelitian (LEMLIT) IAIN

Sunan Ampel Surabaya, 2012.

Mustafa, Zainal. Mengurai Variael Hingga Instrumen. Yogyakarta: Graha Ilmu, 2009.

Nawari. Analisis Regresi dengan MS Exel 2007 dan SPSS. Jakarta: PT. Elex Media Komputindo, 2010.

Noor, Juliansyah. Metode Penelitian: Skripsi, Tesis, Disertasi, dan Karya Ilmiah. Jakarta: Kencana Prenadamedia Group, 2014.

Pace, R. Wayne dan Don F Faules. Komunikasi Organisasi Strategi Meningkatkan Kinerja Perusahaan. Bandung: PT Remaja Rosdakarya, 1998.

Prabawa. "Pengaruh Komunikasi Organisasi dan Gaya Kepemimpinan terhadap Kinerja Karyawan dengan Budaya Organisasi sebagai Variabel Intervening (Studi kasus pada PT. TWC Borobudur, Prambanan.

Prijanto, Budi. et al., "Pengaruh Efektivitas Komunikasi dan Kepemimpinan terhadap Kinerja Organisasi (Studi Kasus: Badan Eksekutif Mahasiswa - Fakultas Ekonomi Universitas Gunadarma Periode 2010-2011), Proceeding Pesat (Psikologi, Ekonomi, Sastra, Arsitektur \& Sipil), Volume 4, Oktober, 2011.

Priyatno, Dwi. Cara Kilat Belajar Analisis Data dengan SPSS 20. Yogyakarta: Penerbit Andi Yogyakarta, 2012. 
Priyatno, Dwi. Mandiri belajar SPSS (statistical product and sevice Solution) untuk Anallisis Data \& uji Statistik. Yogyakarta: Mediakom, 2009.

Rasmuji dan Ratnawati Dwi Putranti. "Pengaruh Efektivitas Kepemimpinan dan Lingkungan Kerja Terhadap Kinerja Karyawan dengan Peran Mediasi Kpeuasan Kerja (Syudi Pada PD. BPR BKK Batang)", Media Eknomi dan Manajemen, No. 2, Vol. 32, Juli, 2017.

Rivai dan Mulyadi. Kepemimpinan dan Perilaku organisasi. edisi ketiga. Jakarta: PT Rajagrafindo Persada, 2010.

Robbins, Stephen P., Perilaku Organisasi. Jakarta: Gramedia Pustaka Utama, 2006.

Seputra, Yulius Eka Agung. Manajemen dan Perlaku Organisasi. Yogyakarta: Graha Ilmu, 2014.

Setiana, Adi Robith Setiana. "Pengaruh Efektivitas Kepemimpinan Kepala Sekolah dan Motivasi Kerja Terhadap Kinerja Guru (Studi Kasus pada MTs Serba Bakti Pondok Pesantren Suryalaya Kab. Tasikmalaya", Jurnal.

Sinambela, Lijan Poltak. Kinerja Pegawai Teori Pengukuran dan Implikasi, Edisi Pertama. Yogyakarta: Graha Ilmu, 2012.

Siregar, Syofian. Metode Penelitian Kuantitatif. Jakarta: Kencana Prenadamedia Group, 2014. Sudarmanto. Kinerja dan Pengembangan Kompetensi SDM. Yogyakarta: Pustaka Pelajar, 2009.

Sugiyono. Metode Penelitian Kuantitatif, Kulaitatif dan $R \& D$. cetakan ke 22 . Bandung: Alfabeta, 2015.
Suharso, Puguh. Metode Penelitian Kuantitatif untuk Bisnis Pendekatan Filosofis dan Praktis. Jakarta: PT Indeks, 2009.

Sutrisno, Edi. Budaya Organisasi. Jakarta: Kencana, 2011. 